\title{
RHYNCHOTA (HETEROPTERA) FROM BRITISH INDIA
}

\section{by W.-L. Distant.}

All the genera and many of the species described in this paper will be figured in the Appendix (vol. V) to the Rhynchotal contribution to the Fauna of British India.

\section{Family BERYTID必.}

Metacanthus bihamatus sp. n. - Pronotum and sternum pale ochraceous; head and a tuberculous spot at each basal angle of the pronotum, shining-black; abdomen beneath, legs, rostrum and antennæ stramineous; numerous annulations to legs and antennæ and apex of rostrum, black; first joint of antennæ about as long as anterior tibiæ and tarsi, its apex moderately clavate, second about two-thirds the length of first and subequal to third; rostrum reaching the posterior coxæ, first joint about reaching the anterior coxæ; pronotum with a distinct anterior collar at the base of which is a long hooked spine on each side, disk of pronotum convexly raised, finely punctate, with a somewhat obscure central longitudinal ridge, and a central small tubercle between the black tuberculous spots; scutellum with a short (in typical specimen probably mutilated) subbasal spine; hemelytra pale shining hyaline, membrane with an iridescent tint and considerably extending beyond abdominal apex.

Length 4 mill.

Hab. : Ceylon (Green. - Brit. Mus.).

A very distinct species; by the long hooked spines to the pronotum denoting a subgeneric division.

\section{Family PYRBHOCORID无.}

Dermantinus erebus sp. n. - Black; finely, shortly, greyishly pilose; femora black, their bases and extreme apices, coxæ, trochanters, the tibiæ and the tarsi brownish ochraceous; antennæ black or piceous; apex of scutellum ochraceous; antennæ finely setose with the second and fourth joints longest and subequal in length; rostrum reaching the posterior coxæ, basal joint castaneous and slightly passing base of head, remaining joints brownish-ochraceous; pronotum very finely granulate and shortly greyishly pilose, the lateral margins shortly but distinctly reflexed, 
basal margin truncate nearly straight; corium reaching the base of the fourth abdominal segment and with its apex truncate.

Length 5 mill.

Hab. : N.-W. India; Lucknow. Ceylon; Hambantula (Fletcher).

Allied to D. lugubris Dist., but smaller in size, the basal margin of the pronotum nearly straight, apical margin of fourth abdominal segment centrally less acutely produced etc.

\section{Family TINGIDID压.}

\section{RECAREDUS gen. nov.}

Head distinctly produced and deflected between the bases of the antennæ, andalso with a distinct lateral curved robust spine between the antennæ and eyes, basal margin moderately concave, eyes transversely rounded; antennæ robust and pilose, the two basal joints short and robust, second shorter than first, third about twice as long as fourth; rostrum extending slightly beyond the posterior coxæ; pronotum with a small vesicle or hood which does not extend beyond base of head, and is convex and areolate, lateral pronotal margins strongly convex and bi-areolate, the disk with three central longitudinal carinations, the central one straight the lateral ones slightly curved, the posterior margin centrally subangularly sinuate; scutellum exposed, subtriangular, areolate, centrally, longitudinally strongly ridged; elytra with the lateral margins nearly straight, subparallel, convexly rounded at apices, costal areas bi-areolate, discoidal and subcostal areas thickly but somewhat smally areolate; sutural area with the areolets as large as those on costal area; legs slender.

This genus apart from the structure of the head has a considerable resemblance to Acalypta Westw., a Palæarctic genus; in the Indian enumeration it may be placed after Phatnoma and probably requires a divisional separation.

Recaredus rex sp. n. - Pale fuscous-brown, the interior of the areolets on pronotal vesicle, lateral pronotal margins, scutellum and costal and sutural areas of the elytra, greyish-white; eyes and antennæ piceous, the latter thickly, strongly and brownly pilose; body beneath and legs castaneous; elytra longly passing the abdominal apex; other structural characters as in generie diagnosis. Length 3 mill.

Hab. : W. Bengal ; Paresnath 4000 to 4400 feet (ANnadanle. Ind. Mus.).

$\mathrm{D}^{\mathrm{r}}$ Annandale discovered a single specimen of this interesting genus and species. 


\section{Family ARADID疋.}

Aradus dignatus sp. n. - Black; antennæ with the first joint black, the second very pale ochraceous with its extreme base black, third stramineous, fourth black; corium pale greyish, claval veins concolorous, costal margin and veins on costal area jet black; membrane hyaline, very indistinctly spotted with pale fuscous on apical margin; head longer than broad, spines at antenniferous tubercles long and prominent; eyes distinctly transversely produced; antennæ with the second joint about four times as long as the first, third gradually thickened from base to apex; rostrum extending beyond the base of the prosternum which is sulcate; pronotum with the anterior margin distinctly broader than base of head but not extending beyond the apices of the eyes, with six longitudinal carinations, the sublateral ones more strongly curved, the two central ones least so, lateral margins rounded and finely crenulate; scutellum elongately triangular, the base much shorter than the lateral margins, the lateral margins elevated; corium at base slightly laterally ampliated, membrane in $\sigma^{2}$. slightly passing the abdominal apex; legs more piceous than black.

Length of 4 mill.

Hab. : W. Bengal; Paresnath, $\mathbf{4 0 0 0}$ to $\mathbf{4 4 0 0}$ feet (Annandale. Indian Mus.).

Aradus antemissus sp. n. - Black; antennæ black with the last joint stramineous, its apex ochraceous; hemelytra resembling those of $A$. dignatus but with the membrane more prominently spotted with pale fuscous; connexivum spotted with pale ochraceous; head longer than broad, spines at antenniferous tubercles long and prominent; eyes transversely produced but not so strongly as in A. dignatas; antennæ somewhat short and robust, second and third joints distinctly incrassated, second about three times as long as first, third and fourth subequal in length; rostrum extending beyond the base of the prosternum which is sulcate; pronotum with the anterior angles more distinctly produced than in $A$. dignatus, anterior margin not or scarcely extending beyond the apices of the eyes, six-carinate, the two central carinations straighter than those of $A$. dignatus, lateral margins rounded and finely crenulate; scutellum a little broader than in A. dignatus; membrane in $q$ not quite reaching the abdominal apex.

Length + $51 / 2$ mill.

Hab. : W. Bengal; Paresnath, 4000 to 4400 feet (Annandale. Indian Mus.). 


\section{Family REDUVIID无.}

Oncocephalus aterrimus sp. n. - Black; spots to connexivum, a single annulation to intermediate femora, two annulations to posterior femora, two annulations to all the tibiæ, tarsi, apices of coxæ and the trochanters ochraceous; head with the anterior lobe about twice as long as the posterior lobe, granulose, transversely impressed between the eyes, a short fine spine at base of antenniferous tubercles; first joint of antennæ outwardly curved, shorter than head, second joint twice as long as first and distinctly pilose; first joint of rostrum reaching eyes; pronotum granulose, with two more or less distinct central longitudinal levigate lines, the anterior angles shortly tuberculously prominent, the lateral margins of the prosternum visible on each side of the lateral margins of the anterior pronotal lobe, anterior lobe a little longer than posterior lobe; prosternum with two strong anterior spines; anterior femora strongly incrassate with a single row of small spines benearth, anterior tibiæ a little curved, about as long as the femora.

Length 12 mill.

Hab. : Travancore; Tenmalai, W. Ghats (ANnANDALE).

I have only seen a single specimen of this very distinct species.

\section{BARDESANES gen. nov.}

Head with the anteocular portion much longer than the postocular, with two horizontally depressed spines before the base of antennæ, the anteocular portion flat, the postocular somewhat convexly gibbous, transversely impressed between the eyes, immediately behind this impression are the ocelli, prominent and nearer to eyes than to each other; antennæ pilose, first joint about as long as pronotum and subequal in length to the second joint; rostrum reaching the anterior coxæ, first joint extending to the anterior margins of the eyes and a little shorter than the second joint; pronotum about as long as broad, concavely sinuately narrowed anteriorly where it is slightly wider than the base of head, the anterior lateral angles subprominent, the posterior angles distinctly shortly spinously prominent, the posterior margin subconvex, straightened before base of scutellum, the anterior margin truncate, moderately transversely depressed a little before middle; scutellum somewhat triangular, the apical spine moderately curved upwards; corium slender, not covering connexivum, its greatest length equal to the corresponding length of membrane 
which is large and broad, a large areole occupying the inner apical area of corium and reaching the membrane; eyes very large and almost meeting beneath the head; prosternum centrally longitudinally sulcate and posteriorly centrally triangularly dilated between the anterior coxæ; abdomen beneath with a fine central longitudinal carinate line; legs slender, anterior femora not thickened, anterior and intermediate femora about equal in length and moderately curved; posterior legs long, the femora not quite reaching abdominal apex and shorter than the tibiæ; posterior tarsi with the second joint shorter than the third, posterior coxæ much wider apart than the intermediate coxæ which are again more widely separated than the anterior coxæ.

A genus to be placed after Caumus in the British Indian enumeration.

Bardesanes signatus sp. n. - Fuscous-brown; eyes, a large spot between and behind ocelli, inner claval margins, the central areole to hemelytra and a curved posteriorly attenuated elongate spot to middle cell of membrane, black; pronotum with narrow lateral margins and a central longitudnal linear fascia, single anteriorly and duplex posteriorly, piceous; tibiæ palely annulate near base, femora piceous-brown at apex; head finely granulose the ocelli bright golden-yellow; membrane very slightly passing abdominal apex; other structural characters as in generic diagnosis.

Length 14 mill.

Hab. : Burma; Karennee (coll. DisT.).

Epirodera bengalensis sp. n. - Black; anteocular portion of head, an oblong spot at apex of corium, rostrum, legs and abdomen beneath ochraceous; femora and tibiæ more or less annulated with piceous; anteocular portion of head longer than postocular which is globose behind eyes; pronotum with the anterior lobe very strongly defined, the anterior angles prominent, two central longitudinal ridges which are curved inwardly near middle; scutellum with the apex narrowly spatulate; membrane reaching abdominal apex; abdomen beneath with a sublateral segmental series of black spots on each side; connexivum ochraceous, spotted with spiceous.

Length 9 mill.

Hab. : Bengal; Pusa.

Reduvius delicatula sp. n. - Head, pronotum and scutellum castaneous-brown; eyes black; antennæ brownish-ochraceous; head 
beneath, rostrum and sternum castaneous brown; abdomen beneath, legs and connexivum ochraceous; corium brownish-ochraceous, clavus (excluting inner margin) and the subclaval area to corium greyish-white; membrane pale fuscous-brown; antennæ with the first joint a little shorter than head and considerably shorter than second joint; head transversely impressed at posterior margins of eyes; anterior lobe of pronotum scarcely longer than posterior lobe, but narrower, more globose and with the anterior angles shortly tuberculously prominent; posterior lobe with the basal angles obtusely broadly subangulate, but very slightly prominent; scutellum apically finely and somewhat longly porrectly spinous; rostrum with the basal joint reaching anterior margin of eyes, distinctly shorter than the second joint; membrane not quite but nearly reaching abdominal apex; connexivum exposed on each side of hemelytra; body and legs more or less finely longly pilose.

Length $81 / 2$ mill.

Hab. : Bengal; Chapra (MackenzIE).

\section{ISDEGARDES gen. nov.}

Head broad, transverse, eyes large, completely extending across the lateral areas of the head; antennæ with the basal joint much shorter than the head but extending a little beyond its apex, second joint slightly more than twice as long as first, slightly longer than third; ocelli prominent, central, slightly behind the posterior margin of the eyes; rostrum with the second joint much longer than the first; pronotum with the anterior lobe subquadrate, longer than the posterior lobe, the anterior angles laminately subangularly moderately prominent, centrally longitudinally impressed, posterior lobe less convex and wider than the anterior lobe, its lateral angles subprominent; scutellum subtriangular, a little foveately depressed before apex which is slender and acuminate; hemelytra elongate, their costal margins parallel, membrane reaching abdominal apex with three cellular areas, the middle largest, the apical narrow, elongate, subtriangular; anterior femora considerably thickened, obtusely broadly angulate beneath a little betore middle, anterior tibiæ short, somewhat broadly compressed and curved, intermediate and posterior legs simple, posterior tibiæ very slightly curved.

This genus is somewhat allied to Reduvius.

Isdegardes melanocephalus sp. n. - Black; antennæ, pronotum, lateral margins of corium, rostrum, body beneath and 
legs, ochraceous; suffusions to sternum and a sublateral longitudinal fascia on each side of abdomen beneath, piceous-black; first joint of antennæ shorter than head, second joint slightly more than twice as long as first and slightly longer than third; ocelli prominent and ochraceous; rostrum robust, second joint much longer than the first; pronotum with the anterior lobe subquadrate, the anterior angles prominent but not spinous, centrally finely, linearly impressed, the impression foveately widened on disk, posterior lobe a little shorter and wider than anterior lobe, the lateral angles subprominent; scutellum with the margins ridged, a little foveately impressed before apex; membrane reaching the abdominal apex; anterior femora strongly incrassated.

Length $81 / 2$ mill.

Hab. : Calcutta.

Acanthaspis bombayensis sp. n. - Black; antennæ, a discal longitudinal stripe on each side of head at inner margins of eyes and a small quadrate spot at base, posterior lobe of pronotum (excluding its anterior margin), a large spot to corium behind middle, spots to connexivum, rostrum and legs ochraceous; bases and apices of femora more or less black (in the typical specimen the left side anterior femur is almost wholly black); first joint of antennæ longly passing apex of head but shorter than the second joint; rostrum robust, basal joint reaching eyes, pronotum with the anterior lobe sculptured and greyishly pilose, the anterior angles very shortly conically prominent, the posterior lobe somewhat transversely rugulose, the posterior lateral angles shortly spinously produced, the spines directed backward; scutellum with a long obliquely erect spine the apex of which is ochraceous; membrane reaching the abdominal apex; body beneath and legs longly greyishly pilose; the spongy furrow to the anterior tibiæ a little more than one third their length.

Length 13 mill.

Hab. : Bombay Prov.; Igatpuri, W. Ghats.

Allied to A. concinnula $\mathrm{STÅL}$.

Scadra militaris sp. n. - Sanguineous ; first and second joints of antennæ, apex of head above, scutellum, a broad longitudinal claval streak, membrane, head beneath, rostrum, sternum and legs black; abdomen beneath sanguineous, with a broad sublateral fascia on each side of disk, black, this fascia is narrowed posteriorly and does not reach the abdominal apex; antennæ with the basal joint a little shorter than head and considerably shorter than second 
joint, remaining joints mutilated in typical specimen; rostrum with the basal joint about as long or a little longer than the remaining joints together; head transversely impressed behind eyes; pronotum with the anterior lobe shorter than the posterior, moderately sculptured, both lobes centrally longitudinally sulcate, the sulcation not reaching base, posterior lobe also longitudinally impressed before each lateral margin; scutellum sculptured, the apical spinous angles curved and a little directed inwardly.

Length 14 mill.

Hab. : Assam; Naga Hills (Doherty).

Scadra atricapilla sp. n. - Sanguineous; head from the transverse impression behind eges to apex, collar, first and second joints of antennæ, scutellum, a broad longitudinal streak to clavus, membrane, head beneath and sternum, black; rostrum and legs piceous-brown, tibiæ annulated with pale ochraceous near base; abdomen beneath sanguineous with a broad longitudinal sublateral black fascia on each side of disk, this fascia a little narrowed posteriorly and not reaching apex; antennæ with the first joint almost as long as head or very slightly shorter, distinctly shorter than second joint, both joints pilose, remaining joints mutilated in typical specimen; rostrum with the basal joint about as long, as remaining joints together; pronotum with the anterior lobe considerably shorter than posterior, roundly narrowed anteriorly, only slightly sculptured, both lobes centrally longitudinally sulcate, the sulcation not extending beyond middle of posterior lobe and with the transverse impressior piceous, posterior lobe with a longitudinal impression before each lateral margin; scutellum moderately foveate at base, the apical spinous angles curved and a little directed inwardly; legs slightly, tibiæ more prominently pilose.

Length 12 mill.

Hab. : Sylhet (Vienna Mus.).

\section{GUIONIUS gen. nov.}

o Head with the anteocular and postocular areas subequal in length, depressed anteriorly with the central lobe prominent at apex, the antenniferous tubercles prominent, the postocular area globose both above and beneath; ocelli very distinct; antennæ with the first joint shorter than head, shorter than second joint, both these joints moderately curved (remaining joints mutilated in typical specimen); ros. trum with the first joint much shorter than second, not reaching eyes, a distinct moderately broad collar at base of head; pronotum with the 
anterior lobe shorter than the posterior, convexly globose, its lateral margins convex, with a broad central foveate sulcation which does not reach anterior margin and is continued on posterior lobe for about half its length, posterior lobe with three longitudinal punctate impressions, one central and one on each lateral area; scutellum broad, transverse, not narrowed posteriorly, apical spines wide apart and slightly curved, the lateral margins ridged; abdomen moderately dilated the connexivum broadly exposed on each side; legs robust, the anterior femora incrassate and armed beneath with a short tuberculous spine on apical area, anterior and intermediate tibiæ with a short apical spongy furrow; membrane not reaching the apical margin.

Allied to Labidocoris by the spinous anterior femora, but differing from that genus by the distinct structure of the head, first joint of the rostrum much shorter than the second, first joint of antennæ shorter than head, etc.

Guionius indictus sp. n. - -. Head, pronotum and scutellum sanguineous; ; first joint of antennæ dull reddish, its apex and the whole of second joint black, body beneath shining black; head beneath, rostrum, prosternum, lateral margins of meso- and metasterna, legs, and lateral margins of abdomen sanguineous, disks of fourth and fifth and nearly the whole of sixth segment dull reddish; apices of tibiæ, and marginal spot to first and second segments black; connexivum (as seen above) sanguineous, with a transverse black spot at the incisures; hemelytra black, corium with the lateral margins widened at posterior angle, sanguineous; structural characters as in generic diagnosis.

Length 18 mill.

Hab. : Assam (coll. Dist.).

Schottus kandyensis sp. n. - Sanguineous; membrane black; corium (excluding extreme costal margin and apical angle) and base of membrane, reddish-ochraceous; antennæ black, first joint sanguineous, basal joint about as long as head, second about one fourth longer than first, third and fourth subequal in length, first and second stoutest, third and fourth slender and pilose; head transversely impressed behind eyes and just before ocelli; rostrum with the first joint longer than second, very little shorter than second and third together; pronotum with the anterior lobe moderately sculptured, centrally longitudinally impressed, posterior lobe centrally and sublaterally longitudinally sulcate, the central sulcation not reaching base; scutellum triangulate posteriorly, the 
mucronate angles widely separated; membrane not quite reaching abdominal apex; anterior femora moderately thickened with a distinct tuberculous spine a little beyond middle of under surface.

Length 11 mill.

Hab. : Ceylon; Kandy (Green).

Harpactor mæandrus sp. n. - Coral-red; antennæ, eyes, a central triangular spot behind ocelli, a large anterior transverse spot to posterior lobe of pronotum, hemelytra, apices of anterior and intermediate femora, the whole of the posterior femora, tibiæ, tarsi excluding base, apical half of rostrum, lateral sternal spots, stigmatal spots and apical third to abdomen beneath, black; head about as long as pronotum, anteocular and postocular areas subequal in length; first joint of antennæ about as long as anterior femora; first joint of rostrum shorter than second and reaching middle of eyes; anterior lobe of pronotum with two small but distinct tubercles on disk a little behind middle, between them a foveate impression, posterior lobe considerably longer than the anterior with the lateral angles broadly subprominent; membrane reaching or very slightly passing the abdominal apex; legs somewhat longly pilose; the coral-red connexivum prominent and recurved on each side of the black hemelytra.

Length 13 mill.

Hab. : Tenasserim (coll. Dist.).

Sphedanolestes Badgleyi sp. n.-- Head, antennæ, rostrum, pronotum, scutellum, sternum and legs black or piceous; a longitudinal fascia to head beneath and the abdomen beneath, ochraceous, the latter with a sublateral series of irregularly placed black spots; hemelytra pale bronzly-brown; head about as long as pronotum, anteocular portion shorter and narrower than the postocular; antennæ with the first joint as long as the anterior femora, almost equal in length to the second joint; rostrum reaching the anterior coxæ, first joint reaching eyes, shorter than second joint; pronotum with both lobes broadly, longitudinally sulcately impressed, posterior angles slightly nodulose, posterior margin straight; femora nodulose; membrane passing the abdominal apex.

Length 11 mill.

Hab. : Assam (BADGley - Brit. Mus.).

Sphedanolestes Bowringi sp. n. - Black; pronotum, scutellum and sternum coral-red; first joint of rostrum (excluding base and apex), a large spot on each side of head in front of eyes 
and beneath base of antennæ, a small spot on each side of head behind eyes and in front of ocelli, connexivum, abdomen beneath and bases of femora pale luteous; two spots on posterior area of connexivum, tessellate markings on each lateral area of abdomen beneath, and abdominal apex, black; first joint of antennæ about as long as anterior femora, black (remaining joints mutilated in typical specimen); anterior lobe of pronotum centrally longitudinally sulcate, posterior lobe centrally broadly impressed; pronotum about as long as heat, basal margin straight, posterior angle a little broadly, roundly prominent; membrane with the apical area brownish ochraceous and considerably passing the abdominal apex; femora nodulose.

Length 9 mill.

Hab : ( India i (Bowring. - Brit. Mus.).

Allied to S. trichrous StÅL, a species I have not seen, but from the description of which S. Bowringi differs by the colour of the rostrum, spots to head, and the colour and markings of the abdomen beneath.

Sphedanolestes himalayensis sp. n. - Head above, antennæ and legs black; anteocular area of head (excludly apical spot) a spot between eyes, and a longitudinal spot behind the transverse impression, extreme base of head, pronotum, scutellum, abdomen above and beneath, sternum and bases of femora sanguineous; head beneath, rostrum, coxæ and trochanters ochraceous; abdomen above apically and sublaterally black; corium pale brownish-ochraceous with the veins darker, membrane pale flavous hyaline; head about as long as pronotum, anteocular a little shorter and narrower than postocu'ar area; antennæ with the first joint as long as the anterior femora; pronotum with the anterior lobe convex, centrally longitudinally sulcate, the posterior lobe centrally broadly impressed, the posterior angles broadly rounded, slightly prominent; rostrum reaching the anterior coxæ, its apex piceous, first joint reaching eyes, shorter than second joint; membrane considerably passing the abdominal apex; body and legs pilose, the legs and margins of connexivum longly pilose.

Lengt 11 mill.

Hab. : East Himaláyas.

By the sanguineous pronotum allied to the preceding species, S. Bowringi (Dist.).

Sphedanolestes rubecula sp. n. - Head and scutellum black; pronotum and sternum sanguineous; abdomen beneath sor- 
didly piceous shaded with black and with a large pale basal spot; legs black, coxæ and extreme bases of anterior femora sanguineous; hemelytra pale bronzy-brown, corium distinctly longitudinally grooved, membrane finely wrinkled; head about as long as pronotum, postocular area a little longer and broader than anteocular area, with two prominent tubercles just behind the transverse impression between the eyes; antennæ with the first joint black about as long as the anterior femora (remaing joints mutilated in typical specimen; pronotum centrally longitudinally impressed on anterior lobe, centrally and broadly impressed on posterior lobe, the posterior angles a little prominent and nodulose, the posterior margin not quite straight, a little concave; rostrum with the first joint reaching eyes, shorter than second joint; membrane considerably passing abdominal apex; femora regularly nodulose; legs somewhat longly pilose.

Length 8 mill.

Hab. : Mergui (coll. Dist.).

Macracanthopsis nigripes sp. n. - Head pronotum, scutellum and body beneath luteous; antennæ and spines behind their base, eyes, hemelytra, legs and lateral margins of abdomen beneath, black; abdomen beneath more stramineous than luteous; antennæ with the first joint as long as the head, pronotum and scutellum together; head about as long as pronotum, transversely impressed between the eyes, spines behind base of antennæ long, obliquely upwardly directed, first joint of rostrum much shorter than second, second about as long as first and third together; pronoturn with the anterior lobe tumid and centrally impressed, posterior lobe centrally foveately impressed, the impression not reaching the posterior margin; anterior femora moderately incrassated and nodulose, apices of intermediate and posterior femora nodulose.

Lengt $81 / 2$ mill.

Hab. : Travancore; Pallode near Trivandrum and Maddathoray, W. Ghats (ANNANDALE).

Allied to $M$. nodipes Reut. but smaller, first joint of antennæ longer, spines behind antennal bases also a little longer and more slender, legs black, etc.

Macracanthopsis Hampsoni sp. n. - Head, pronotum and scutellum pale ochraceous; two central longitudinal lines to head from ocelli to base, and a broad sublateral fascia on each side of pronotum black; body beneath and legs stramineous, abdomen beneath with a longitudinal sublateral black fascia, the legs obscure 
annulated with black; hemelytra black, about apical half of membrane pale hyaline; head about as long as pronotum, anteocular distinctly shorter than postocular area, a long obliquely erect black spine behind the base of each antenna which are black and the first joint of which is slightly longer than head and pronotum to gether; first joint of rostrum not reaching eyes, much shorter than second joint; pronotum with the anterior lobe tumid and centrally impressed, the anterior angles short but distinct, posterior lobe centrally foveately impressed, the posterior angles moderately but distinctly subangularly prominent; scutellum with the margins and apex carinately elevate ; membrane longly passing the abdominal apex; legs slender, anterior femora moderately incrassated and nodulose, apices of intermediate and posterior femora nodulose.

Length 12 mill.

Hab. : Nilgiri Hills (HAMPSON).

OCCAMUS gen. nov.

Head about as long as pronotum, transversely impressed between eyes, ante-ocular much shorter than post-ocul ir area, a short tuberculous spine above bases of antennæ, post-ocular area attenuated towards base; antennæslender, first joint about as long as anterior femora, slightly shorter than second; rostrum with the first joint passing eyes, first and second joints subequal in length; pronotum with the anterior lobe shorter than the posterior, moderately globose and sculptured, with a distinct short suberect spine at each anterior angle, posterior lobe with a much longer almost straight slender spine at each lateral angle, and two shorter erect spines on disk a little before base, posterior margin sinuate; scutellum with two spines, one near base almost straight, the other at apex long and strongly recurved; anterior femora moderately regularly thickened, straight, the anterior tibiæ only very slightly shorter than the femora, curved, their apices slightly dilated and truncale, intermediate and posterior legs slender; membrane not reaching the abdominal apex.

Allied to Alcmena STÅ.

Occamus typicus sp. n. - Head, antennæ and pronotum brownish-ochraceous; body beneath, rostrum and legs ochraceous, apical area of abdomen, above and beneath, piceous or black, but even there the connexivum is ochraceous; corium ochraceous; membrane dull greyish; body finely pilose, legs much more longly 
pilose; femora obscurely fuscously annulate near apices; apex of first joint of antennæ fuscous; structural characters as in generic diagnosis.

Length 12 mill.

Hab. : Ceylon; Peradeniya (Green).

Nagusta singalensis sp. n. - Head uniformly black or fuscous; antennæ uniformly brownish-ochraceous; pronotum, scutellum, and hemelytra more or less testaceous-brown sprinkled with cinereous; rostrum and legs brownish-ochraceous, body beneath cinereous speckled with brownish, abdomen beneath with a central longitudinal brown line; first joint of antennæ almost as long as head and pronotum together, second joint a little shorter than first; rostrum with the first joint a little longer than the remaining joints together; head with an oblique spine behind the base of each antenna, the postocular portion a little more than twice as long as the anteocular portion; pronotum a little shorter than the head, the posterior lobe very obtusely bituberculate near base, the lateral angles produced in slender brown spines which are a little recurved; hemelytra nearly reaching the abdominal apex, the discoidal cell a little longer than broad, membrane glossy cinereous brown, the veins prominent and piceous.

Length $\sigma^{1} 13$ mill.

Hab. : Ceylon; Peradeniya (Green).

Allied to $N$. macroloba Bergr. but with the discoidal cell of the corium distinctly longer than broad and with the antennæ and legs concolorous, not palely annulated; head uniformly black, etc.

Henricohahnia Badgleyi sp. n. - Head, pronotum and sternum dull black; rostrum, legs, abdomen beneath and hemelytra castaneous-brown; antennæ with the first joint black, moderately thickened, about as long as the postocular portion of the head, second joint ochraceous, about twice as long as first (remaining joints mutilated in typical specimen); head coarsely punctate, shortly spinous on lateral margins, postocular portion a little longer than anteocular portion, the central lobe prominent and spinously anteriorly produced; rostrum with the first joint short, about reaching eyes, second joint twice as long as first; pronotum with the posterior lateral angles subprominent not spinous, the lateral margins sinuate and narrowing anteriorly, the anterior half with longitudinal series of punctures and with a faint central longitudinal impression, the posterior area thickly punctate and finely rugulose; clavus more or less ochraceous, the apex black; 
connexivum in $\sigma$, exposed beyond the middle of the hemelytra and there exhibiting two ochraceous spots; abdomen beneath longitudinally paler on disk; femora more or less granulose, the anterior femora distinctly thickened and laterally spined along inner margin. Length $0^{1} 12$ mill., breadth between pronot. angles 3 mill.

Hab. : Assam ( Badgley. - Brit. Mus.).

Allæorhynchus collaris sp. n. - Head and pronotum glossy black; anterior margin of pronotum somewhat broadly ochraceous; scutellum black; corium ochraceous with about apical half and clavus, black; membrane pale fuscous; connexivum ochraceous spotted with black; body beneath black; rostrum, legs and anterior margin of prosternum ochraceous; antennæ with the first and second joints ochraceous, the second a little darker and more than half as long again as first; pronotum with the anterior lobe longer than the posterior, its disk convex, its lateral margins rounded, posterior lobe broader than anterior, its lateral margins obliquely rounded, lateral margins of both lobes longly palely pilose; membrane not reaching the abdominal apex; rostrum with the second joint longer than third; anterior and intermediate femora moderately incrassated and medially obtusely somewhat dentately ampliated.

Length o, 6 mill.

Hab. : N. W. India; Kumaon.

In colour markings most closely allied to the Ceylonese species A. Nietneri SteIn, which I have not seen.

Nabis mussooriensis sp. n. - Head black with a short oblique ochraceous line proceeding from inner margin of each eye towards base; pronotum brownish-ochraceous, anterior lobe with the anterior and lateral margins and a central spot before the transverse impression piceous or black, posterior lobe much suffused with piceous and with an anterior central quadrate piceous spot; scutellum black; hemelytra piceous-black, apex of clavus ochraceous, apical margin of membrane with small scattered ochraceous spots; connexivum black with small transverse ochraceous spots, body beneath piceous or black; legs brownish ochraceous, more or less annulated with piceous, femora with a broad subapical annulation, tibiæ more regularly and narrowly annulated; antennæ brownish ochraceous, first and second joints annulated with piceous, first joint about as long as head, second and third about equally long and each considerably longer than first; rostrum about reaching the intermediate coxæ, first joint black, remainder 
brownish ochraceous, annulated with piceous; pronotum elongate, anterior lobe longer than the posterior and with a distinct anterior collar, its disk moderately convex and its lateral margins roundly sinuate, posteriør lobe broadly ridged at base; scutellum foveately impressed on disk; corium moderately ampliately rounded near middle; membrane slightly passing the abdominal apex; abdomen beneath thickly, finely, greyishly sericeous.

Length of, 9 mill.

Hab. : N. W. India; Mussoorie.

This species appertains to the subgenus Eptus HAHN, and is allied to the South African N. (Eptus) hottentota Reut.

\section{Famly S ALDID无.}

Salda inconstans sp. n. - Pitchy-black, thickly shortly palely pilose; legs ochraceous, more or less streaked with black orpiceous; corium spotted with greyish-ochraceous, first and second spots at about one third from base and each enclosing a dark spot, one on each side of apex of clavus, two (larger) near each of these on corium, a large irregular spot on disk of corium before membrane and another spot on subcostal area near apex; membrane pale greyishochraceous, a black spot near each outer margin, the apex and central longitudinal suffusions pale fuseous, the base narrowly piceous; antennæ with the third and fourth joints subequal in length or third slightly longer than fourth; rostrum reaching the posterior coxæ; pronotum more than twice broader than long, the lateral margins roundly oblique, the posterior margin moderatly concavely sinuate before scutellum, and with a transverse impression on disk; scutellum broad, transversely impressed before middle; corium with the costal margin moderately convexly rounded; membrane passing the abdominal apex; tibiæ spinulose.

Var. a. Corium with a single ochraceous spot on costal margin before apex, membrane darker the suffusions piceous.

Var. $b$. Corium with a central apical pale spot before membrane with is marked and shaded as in typical form.

Length $41 / 2$ mill.

Hab. : Punjab; Simla Hills, Matiana (Annandale).

Under stones at edges of mountain streams; jumping and flying at edge of pond (N. AnNandale).

Salda Fletcheri sp. n. - Black; apical joint of antennæ, rostrum, coxæ, legs and abdominal segmental margins more or less ochraceous; corium black with the costal margin, a spot near 
apex and base of each side of clavus, a basal longitudinal streak, four spots on subcostal area and three on inner area ochraceous, those on the subcostal area somewhat whitish; membrane piceous, the lateral margins and a transverse series of four spots behind middle ochraceous, nearer base a transverse series of more obscure spots; antennæ with the third and fourth joints subequal in length, second longest; pronotum with the basal margin strongly concavely sinuate before scutellum, the lateral margins oblique, a little sinuate, the anterior margin about half the breadth between posterior angles; corium somewhat convexly rounded at costal margin; scutellum foveately impressed on disk ; rostrum reaching the posterior coxæ; tibiæ distinctly spinulose.

Length $41 / 2$ mill.

Hab.: Ceylon; Madulsima (Bainbrigge-Fletcher. - Brit. Mus.).

Salda pusana sp. n. - Allied to S. Fletcheri Dist., but with the antennæ and rostrum wholly black; legs black, base of anterior femora and more than basal halves of intermediate and posterior femora, and basal annulations to tibiæ, pale ochraceous; corium with the pale costal margin narrowed and somewhat interrupted before apex, the spots on subcostal area three in number; antennæ with the third joint slightly longer than fourth, other structural characters as in S. fletcheri.

Length 4 1/2 mill.

Hab. : Bengal; Lebong, 5000 feet (LeFroy).

$\mathrm{M}^{\mathrm{r}}$ LEFROY send me three specimens of this species (all unfortunately more or less mutilated in condition) fron the Pusa collection. 


\section{$2 \mathrm{BHL}$ Biodiversity Heritage Library}

1909. "Rhynchota (Heteroptera) from British India." Annales de la Société entomologique de Belgique 53, 360-376. https://doi.org/10.5962/bhl.part.21876

View This Item Online: $\underline{\text { https://www.biodiversitylibrary.org/item/46155 }}$

DOI: https://doi.org/10.5962/bhl.part.21876

Permalink: https://www.biodiversitylibrary.org/partpdf/21876

\section{Holding Institution}

Smithsonian Libraries

\section{Sponsored by}

Smithsonian

\section{Copyright \& Reuse}

Copyright Status: NOT_IN_COPYRIGHT

This document was created from content at the Biodiversity Heritage Library, the world's largest open access digital library for biodiversity literature and archives. Visit BHL at https://www.biodiversitylibrary.org. 